\title{
Interspecific variability of class II hydrophobin GEO1 in the genus Geosmithia
}

\author{
Arcangela FRASCELLA ${ }^{a, b}$, Priscilla P. BETTINI ${ }^{a, *}$, Miroslav KOLAŘ́í ${ }^{c}$, \\ Cecilia COMPARINI ${ }^{b}$, Luigia PAZZAGLI ${ }^{d}$, Simone LUTI $^{d}$, Felice SCALA, \\ Aniello SCALA ${ }^{b}$ \\ ${ }^{a}$ Dipartimento di Biologia, Università di Firenze, via Madonna del Piano 6, 50019 Sesto Fiorentino, FI, Italy \\ bipartimento di Scienze delle Produzioni Agroalimentari e dell'Ambiente (DISPAA), Università di Firenze, \\ via della Lastruccia 10, 50019 Sesto Fiorentino, FI, Italy \\ 'Institute of Microbiology of the ASCR, v.v.i, Videnská 1083, 14220 Praha 4, Czech Republic \\ ${ }^{\mathrm{d} D i p a r t i m e n t o ~ d i ~ S c i e n z e ~ B i o m e d i c h e, ~ S p e r i m e n t a l i ~ e ~ C l i n i c h e, ~ U n i v e r s i t a ̀ ~ d i ~ F i r e n z e, ~ V i a l e ~ M o r g a g n i ~ 50, ~}$ \\ 50134 Florence, Italy \\ eDipartimento di Arboricoltura, Botanica e Patologia Vegetale, Sezione di Patologia Vegetale, \\ Università di Napoli "Federico II", via Università 100, 80055 Portici, NA, Italy
}

\section{A R T I C L E I N F O}

\section{Article history:}

Received 30 November 2013

Received in revised form

4 July 2014

Accepted 28 July 2014

Available online 12 August 2014

Corresponding Editor:

Barbara Schulz

Keywords:

Ascomycetes

Genetic diversity

Hypocreales

Intragenic tandem repeats

Protein evolution

\begin{abstract}
A B S T R A C T
The genus Geosmithia Pitt (Ascomycota: Hypocreales) comprises cosmopolite fungi living in the galleries built by phloeophagous insects. Following the characterization in Geosmithia species 5 of the class II hydrophobin GEO1 and of the corresponding gene, the presence of the geo1 gene was investigated in 26 strains derived from different host plants and geographic locations and representing the whole phylogenetic diversity of the genus. The geo1 gene was detected in all the species tested where it maintained the general organization shown in Geosmithia species 5, comprising three exons and two introns. Size variations were found in both introns and in the first exon, the latter being due to the presence of an intragenic tandem repeat sequence corresponding to a stretch of glycine residues in the deduced proteins. At the amino acid level the deduced proteins had $44.6 \%$ identity and no major differences in the biochemical parameters (pI, GRAVY index, hydropathy plots) were found. GEO1 release in the fungal culture medium was also assessed by turbidimetric assay and SDS-PAGE, and showed high variability between species. The phylogeny based on the geo1 sequences did not correspond to that generated from a neutral marker (ITS rDNA), suggesting that sequence similarities could be influenced by other factors than phylogenetic relatedness, such as the intimacy of the symbiosis with insect vectors. The hypothesis of a strong selection pressure on the geo1 gene was sustained by the low values $(<1)$ of non synonymous to synonymous nucleotide substitutions ratios $(\mathrm{Ka} / \mathrm{Ks})$, which suggest that purifying selection might act on this gene. These results are compatible with either a birth-and-death evolution scenario or horizontal transfer of the gene between Geosmithia species.
\end{abstract}

(C) 2014 The British Mycological Society. Published by Elsevier Ltd. All rights reserved.

\footnotetext{
* Corresponding author. Tel.: +39 (0)55 457 4741; fax: +39 (0)55 4574905.

E-mail addresses: affabula@gmail.com (A. Frascella), p.bettini@unifi.it (P. P. Bettini), mkolarik@biomed.cas.cz (M. Kolařík), cecilia.comparini@unifi.it (C. Comparini), luigia.pazzagli@unifi.it (L. Pazzagli), simone.luti@unifi.it (S. Luti), felice.scala@unina.it (F. Scala), aniello.scala@unifi.it (A. Scala). 


\section{Introduction}

The monophyletic genus Geosmithia Pitt (Ascomycota: Hypocreales) comprises 32 published species of mitosporic fungi mostly associated with phloem-feeding bark beetles belonging to the Scolytids and Bostrichis (Kolařík et al. 2004, 2005, 2007, 2008, 2011; Kolařík \& Kirkendall 2010; Kolařík 2012; Kolařík \& Jankowiak 2013). Geosmithia fungi are mainly insect-associated but can also live on various plant substrates without relation to insects, soil, foodstuffs and as true plant endophytes (Kolařík et al. 2004, 2008; Kolařík \& Jankowiak 2013; McPherson et al. 2013). Two primary ambrosia fungi, Geosmithia eupagioceri and Geosmithia microcorthyli, associated with beetle species in Costa Rica, have also been described (Kolařík \& Kirkendall 2010). Only one phytopathogenic species has been identified so far, Geosmithia morbida, the causal agent of thousand-canker disease of black walnut in USA (Kolařík et al. 2011). However, Čížková et al. (2005) reported an inhibitory effect on stem and root elongation in oak plants for the species Geosmithia pallida and Geosmithia langdonii.

Geosmithia are abundant associates of numerous subcortical insects worldwide, and there is growing evidence that this association is consistent and evolutionarily stable. The most convincing proof is the presence of true ambrosia species, of the bark beetle-vectored phytopathogenic species $G$. morbida and the fact that some species are specialists restricted to several insect vectors and host plants over large geographical areas (Kolař́k et al. 2008; Kolařík \& Jankowiak 2013). Insect vectors infest hardwoods and conifers and are widespread in central Europe and in the tropics of America, Asia and Australia. The advantage for the beetles of the association with Geosmithia is still unclear, except in the case of ambrosia species; fungi can provide food for the insects or affect their fitness through the production of secondary metabolites i.e. hydroxylated anthraquinones, that could inhibit detrimental microbes for the host beetle as well as acting as repellents towards the beetle's predators (Stodulková et al. 2009). Kolařík \& Kirkendall (2010) have proposed that the association of fungi with phloeophagous bark beetles was evolutionarily ancestral, followed by at least three independent shifts to obligate association with ambrosia beetles and then by fundamental morphological adaptations.

Bettini et al. (2012) have recently reported on the isolation in Geosmithia species 5 strain IVV7 of a new class II hydrophobin, called GEO1, and of the corresponding gene. Hydrophobins are small proteins produced by filamentous fungi whose main characteristic is the ability to assemble at the hydrophilic/hydrophobic interfaces forming an amphipathic membrane (Sunde et al. 2008). They have been divided in two classes based on their solubility, hydropathy patterns and amino acid sequences: class I hydrophobins are produced by ascomycetes and basidiomycetes, while class II hydrophobins are produced only by ascomycetes (Whiteford \& Spanu 2002; Linder et al. 2005). Hydrophobins are involved in fungal development and in the interaction between fungi and their hosts, being in some cases pathogenicity factors. In particular, they can mediate the attachment of fungi to hydrophobic surfaces, such as plant cuticle, lignin, or insect exoskeleton (Wösten et al. 1994; Temple \& Horgen 2000; Zhang et al. 2011).
Conidia produced by Geosmithia are dry and hydrophobic as in airborne fungi (Kolařík et al. 2008), at variance with other entomochoric species, such as the Ophiostoma, which produce sticky conidia. The GEO1 hydrophobin could therefore favour the dissemination of the fungus by virtue of the hydrophobicity conferred to the conidia, which would allow it to establish hydrophobic interactions between the chitinous exoskeleton of the insect vectors and the conidia themselves (Temple \& Horgen 2000; Zhang et al. 2011).

With the aim of studying the variability of GEO1 in Geosmithia species, in the present paper we describe the characterization of the geo1 nucleotide sequences and of the deduced proteins in 26 species representing the phylogenetic diversity of the genus, isolated from different host plants and geographic locations.

\section{Materials and methods}

\section{Fungal strains and culture}

The Geosmithia strains representing 26 different species used in this study (Table 1) were isolated from insects as described (Kolařík et al. 2007, 2008; Kolařík \& Jankowiak 2013) and maintained on Potato Dextrose Agar medium (BD DifCo ${ }^{\mathrm{TM}}$ ). Plates were incubated in the dark at $24 \pm 1{ }^{\circ} \mathrm{C}$. For liquid culture, an agar plug was transferred to $100 \mathrm{ml}$ flasks containing $20 \mathrm{ml}$ of Takai medium modified as described in Scala et al. (1994). Flasks were wrapped in aluminium foil and incubated on a rotary shaker at $100 \mathrm{rpm}$ at $24 \pm 1{ }^{\circ} \mathrm{C}$. To recover the mycelium cultures were centrifuged at $2500 \mathrm{rcf}$ for $20 \mathrm{~min}$ at room temperature and pellets were stored at $-20^{\circ} \mathrm{C}$.

\section{DNA extraction and Polymerase Chain Reaction (PCR)}

Genomic DNA extraction from mycelium was carried out with the NucleoSpin Plant II kit (Macherey-Nagel GmbH \& Co. KG) following the manufacturer's instructions. DNA concentration was evaluated with a Qubit ${ }^{\circledR} 2.0$ fluorometer (Invitrogen by Life Technologies), and PCR amplifications were carried out on 50 ng of DNA as described (Bettini et al. 2012). For the amplification of the geo1 gene (GenBank accession no. JQ042234) the following primers were used: 5'-AAATGAAGTCCTTTGCCATCA-3' (forward) and 5'-GAGAGTAACCCGGCACTTAGC-3' (reverse).

\section{DNA sequencing and bioinformatic analysis}

Sequencing of the amplified fragments was carried out by Eurofins MWG Operon (Ebersberg, Germany), on either purified PCR products or on bands extracted from agarose gels with the NucleoSpin Gel and PCR Cleanup kit (Macherey-Nagel GmbH \& Co. KG).

Sequences were aligned with MUSCLE (Edgar 2004). Nucleotide diversity $(\pi)$, DNA polymorphism and the ratio of the number of non synonymous $(\mathrm{Ka})$ to synonymous $(\mathrm{Ks})$ substitutions for all pairwise comparisons of the 27 sequences coding for the premature protein, including that of our reference strain Geosmithia sp. 5 IVV7, were calculated with DnaSP 
Table 1 - Geosmithia species and strains used in the present study. Strains denoted by CCF code are deposited in the Culture Collection of Fungi (Prague, Czech Republic). Species numbering is from Kolařík et al. $(2007,2008)$ and Kolařik \& Jankowiak (2013).

\begin{tabular}{|c|c|c|c|c|c|}
\hline Species & Strain no/CCF code & Source & Geographic origin & Reference & $\begin{array}{c}\text { EMBL accession } \\
\text { number }\end{array}$ \\
\hline Geosmithia species 1 & MK1724/CCF3660 & Xylocleptes bispinus on Clematis vitalba & Břeclav, Bulhary, Czech Republic & Kolařík et al. 2007, 2008 & HG792076 \\
\hline Geosmithia species 2 & MK1510/CCF4270 & Scolytus multistriatus on Ulmus minor & Termoli (CB) Italy & Kolařík et al. 2004, 2008 & HG792077 \\
\hline Geosmithia species 3 & MK134/CCF3336 & Scolytus rugulosus on Malus domestica & Opočno, Louny, Czech Republic & Kolařík et al. 2004, 2008 & HG792078 \\
\hline Geosmithia species 4 & MK1722/CCF4278 & Pteleobius vittatus on Ulmus laevis & Břeclav, Kančí Obora, Czech Republic & Kolařík et al. 2008 & HG792079 \\
\hline Geosmithia species 5 & IVV7/CCF4872 & Elm tree affected by DED & Vibo Valentia (RC) Italy & Scala et al. 2007 & JQ042234 \\
\hline Geosmithia putterillii & U131a/CCF4202 & Phloeosinus sequoiae on Sequoia sempervirens & Bohemian river, CA, USA & Kolařík et al. unpublished & HG792080 \\
\hline Geosmithia flava & MK264/CCF3354 & Leprisinus fraxini on Fraxinus excelsior & Muráň plain, Slovakia & Kolarík et al. 2004 & HG792081 \\
\hline Geosmithia species 8 & MK263/CCF4528 & Scolytus intricatus on Quercus dalechampii & šiance hill, Muráňská planina, Slovakia & Kolař́k et al. 2008 & HG792082 \\
\hline Geosmithia species 9 & RJ113k/CCF4311 & Cryphalus piceae on Abies alba & Czajowice, Poland & Kolařík \& Jankowiak 2013 & HG792083 \\
\hline Geosmithia species 10 & MK1788/CCF4286 & Hypoborus ficus on Ficus carica & Suvalan, Azerbaijan & Kolařík et al. 2007, 2008 & HG792084 \\
\hline Geosmithia species 11 & MK551/CCF3555 & Scolytus intricatus on Quercus pubescens & Vilányi hegy Mts., Vokány, Hungary & Kolařík et al. 2008 & HG792085 \\
\hline Geosmithia species 12 & MK661/CCF3557 & Leperisinus orni on Fraxinus excelsior & $\begin{array}{l}\text { Balaton region, Szent Győrgy hegy hill, } \\
\text { Hungary }\end{array}$ & Kolarík et al. 2008 & HG792086 \\
\hline Geosmithia species 13 & MK1515a/CCF4871 & Pteleobius vittatus on Ulmus minor & Milovický les, Bulhary, Czech Republic & Kolařík et al. 2008 & HG792087 \\
\hline Geosmithia langdonii & MK1619/CCF4272 & Bostrichid beetle on Pistacia lentiscus & Sesimbra, Portugal & Kolarík et al. 2005 & HG792101 \\
\hline Geosmithia obscura & MK616/CCF3425 & Scolytus carpini on Carpinus betulus & $\begin{array}{l}\text { Bakony range, Vinye near of Fodöfö, } \\
\text { Hungary }\end{array}$ & Kolařík et al. 2005 & HG792088 \\
\hline Geosmithia lavendula & MK1781/CCF4285 & Hypoborus ficus on Ficus carica & Baki Sahari, Baku, Azerbaijan & Kolař́k et al. 2007 & HG792089 \\
\hline Geosmithia species 21 & MK1761/CCF4280 & Hypoborus ficus on Ficus carica & Wadi al Furiáh, west bank, Israel & Kolař́ík et al. 2007 & HG792090 \\
\hline Geosmithia species 22 & MK739/CCF3645 & Phloetribus scarabeoides on Olea europaea & Wadi al Mujib, Jordan & Kolařík et al. 2007 & HG792091 \\
\hline Geosmithia species 23 & MK781/CCF3639 & Scolytus rugulosus on Prunus armeniaca & Demircili, Silifke, Içel Province, Turkey & Kolařík et al. 2007 & HG792092 \\
\hline Geosmithia species 25 & MK1829a/CCF4211 & Cryphalus piceae on Abies alba & Pašínovice, Czech Republic & Kolařík \& Jankowiak 2013 & HG792093 \\
\hline Geosmithia species 26 & MK1828/CCF4293 & Pityophthorus pityographus on Pinus sylvestrus & Sedlčany, Czech Republic & Kolařík \& Jankowiak 2013 & HG792094 \\
\hline Geosmithia species 28 & RJ279m/CCF4210 & Polygraphus polygraphus on Picea abies & Chyszówki, Poland & Kolařík \& Jankowiak 2013 & HG792095 \\
\hline Geosmithia species 29 & MK1809b/CCF4199 & $\begin{array}{l}\text { Cryphalus piceae, Pityophthorus } \\
\text { pityographus on Abies alba }\end{array}$ & Příběnice, Czech Republic & Kolařík \& Jankowiak 2013 & HG792096 \\
\hline Geosmithia species 31 & U316/CCF4328 & Bark beetle on Pinus muricata & Monterey, CA, USA & Kolařík et al. unpublished & HG792097 \\
\hline Geosmithia eupagioceri & CCF3754 & Eupagiocerus dentipes on Paullinia renesii & Heredia, Birrn', Costa Rica & Kolařík \& Kirkendall 2010 & HG792098 \\
\hline Geosmithia microcorthyli & CCF3861 & Microcorthylus species on Cassia grandis & Heredia, Birr', Costa Rica & Kolařík \& Kirkendall 2010 & HG792099 \\
\hline Geosmithia rufescens & MK1821/CCF4524 & Cnesinus lecontei on Croton draco & Heredia, Birn', Costa Rica & Kolařík \& Kirkendall 2010 & HG792100 \\
\hline
\end{tabular}


Table 2 - . Level of DNA polymorphism for the geo1 gene region in the Geosmithia species under study.

\begin{tabular}{lllll} 
& \multicolumn{1}{c}{$\begin{array}{c}\text { Entire } \\
\text { region }\end{array}$} & $\begin{array}{c}\text { Transcriptional } \\
\text { unit }\end{array}$ & First intron & Second intron \\
\hline No. of sites & 536 & 339 & 109 & 86 \\
No. of polymorphic sites & $175(32.6 \%)$ & $125(36.3 \%)$ & $24(22 \%)$ & $31(36 \%)$ \\
Total no. of mutations & 224 & 156 & 34 & 44 \\
Nucleotide diversity $(\pi)$ & 0.12941 & 0.11325 & 0.17394 & 0.18598 \\
\hline
\end{tabular}

version 5.10.01 (Librado \& Rozas 2009). It is generally assumed that a $\mathrm{Ka} / \mathrm{Ks}$ ratio $>1$ indicates positive selection, a ratio $<1$ negative or purifying selection, while a ratio $=1$ indicates neutral evolution. Tools at the ExPASy Bioinformatics Resource Portal (Translate, ProtScale, ProtParam, PDB Sequence Viewer) (Gasteiger et al. 2003) were used for the characterization of the predicted GEO1 proteins. The ITS rDNA tree was constructed based on previously published sequences (Kolařík et al. 2007, 2008; Kolařík \& Jankowiak 2013) together with five sequences generated during this study, using the methods of Kolarík \& Jankowiak (2013). The known sequence of Geosmithia sp. 26, representing a probable pseudogene, was hardly alignable (Kolařík \& Jankowiak 2013) and was excluded. The dataset contained 26 sequences with 509 positions (97 variables). In case of the geo1 dataset, the final DNA sequence alignment contained 27 sequences with 540 positions (240 variables). All alignments were done in MUSCLE. Phylogenetic trees were obtained with PhyML 3.0 (Guindon et al. 2010) using the $\mathrm{K} 2+\mathrm{G}+\mathrm{I}$ model (for ITS) and HKY $+\mathrm{G}$ (for geo1) estimated in MEGA5 (Tamura et al. 2011).

\section{GEO1 production assay}

The amount of GEO1 excreted in the culture medium was evaluated with a modified turbidimetric assay (Takai \& Richards 1978; Scala et al. 1994). Starter cultures were prepared for each species, including Geosmithia sp. 5 strain IVV7 as a control, by transferring an agar plug in $5 \mathrm{ml}$ of liquid modified Takai medium (Scala et al. 1994) and incubating as described (section 2.1). After 2 d $5 \times 10^{7}$ conidia were inoculated in $100 \mathrm{ml}$ flasks containing $35 \mathrm{ml}$ of modified liquid Takai medium and fungi were grown for 4, 9, 14 and $20 \mathrm{~d}$ either in agitation or in static culture. Samples were in triplicate. At each time point $6 \mathrm{ml}$ were collected from each flask and centrifuged as described (section 2.1). The pellets were lyophilized to determine the dry weight of the mycelium while the supernatants were used for the turbidimetric assay. One milliliter of the supernatant was agitated by vortexing at maximum speed for $2 \mathrm{~min}$ and the absorbance at $400 \mathrm{~nm}$ of the sample was immediately read (Uvikon 860 Double-beam Spectrophotometer, Kontron Instruments). The linear range of the
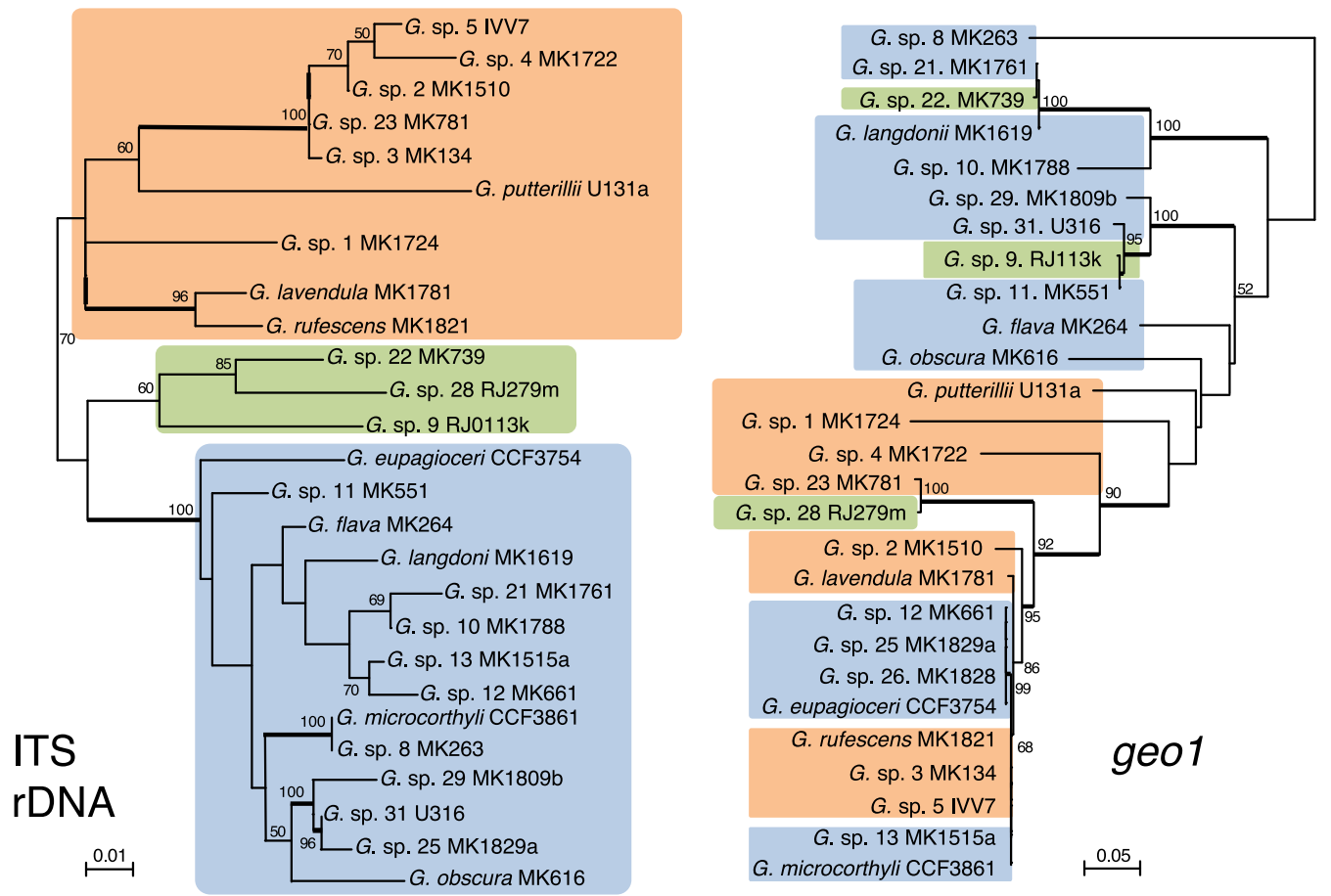

Fig 1 - Maximum likelihood trees of the Geosmithia species used in this study based on ITS rDNA gene or on the genomic sequences of the geo1 gene. Phylogenetic trees were constructed with PhyML 3.0 performing bootstrap analysis with 500 replicates. Thicker lines indicate strongly supported branches (bootstrap values $>90$ ). 
Table 3 - Ratio of non synonymous $(\mathrm{Ka})$ to synonymous (Ks) nucleotide substitutions for pairwise comparisons of the geo1 gene coding region between the Geosmithia spp. used in the present study.

\begin{tabular}{lc} 
Species, strain no. & Average Ka/Ks \\
\hline Geosmithia sp. 1, MK1724 & 0.310 \\
Geosmithia sp. 2, MK1510 & 0.444 \\
Geosmithia sp. 3, MK134 & 0.276 \\
Geosmithia sp. 4, MK1722 & 0.318 \\
Geosmithia sp. 5, IVV7 & 0.276 \\
Geosmithia putterillii, U131a & 0.402 \\
Geosmithia flava, MK264 & 0.493 \\
Geosmithia sp. 8, MK263 & 0.816 \\
Geosmithia sp. 9, RJ113k & 0.442 \\
Geosmithia sp. 10, MK1788 & 0.289 \\
Geosmithia sp. 11, MK551 & 0.407 \\
Geosmithia sp. 12, MK661 & 0.345 \\
Geosmithia sp. 13, MK1515 & 0.276 \\
Geosmithia langdonii, MK1619 & 0.294 \\
Geosmithia obscura, MK616 & 0.294 \\
Geosmithia lavendula, MK1781 & 0.343 \\
Geosmithia sp. 21, MK1761 & 0.294 \\
Geosmithia sp. 22, MK739 & 0.294 \\
Geosmithia sp. 23, MK781 & 0.234 \\
Geosmithia sp. 25, MK1829a & 0.345 \\
Geosmithia sp. 26, MK1828 & 0.345 \\
Geosmithia sp. 28, RJ279m & 0.202 \\
Geosmithia sp. 29, MK1809b & 0.420 \\
Geosmithia sp. 31, U316 & 0.421 \\
Geosmithia eupagioceri & 0.345 \\
Geosmithia microcorthyli & 0.276 \\
Geosmithia rufescens, MK1821 & 0.276 \\
\hline
\end{tabular}

assay was from 0.100 to 3.0. Tukey test was carried out with PAST 3.x (Hammer et al. 2001) to assess the significance of the observed differences.

\section{Protein precipitation and polyacrylamide gel electrophoresis (PAGE)}

One milliliter of supernatant from the turbidimetric assay after $20 \mathrm{~d}$ of growth (section 2.4) was used for protein precipitation. After adding ethanol to a final concentration of $60 \%$, samples were agitated by vortexing and centrifuged at $8000 \mathrm{rpm}$ for $5 \mathrm{~min}$ (MiniSpin ${ }^{\circledR}$, Eppendorf AG, Germany). Three-hundred microliters of ethanol extract were vacuum dried and then dissolved in $40 \mu \mathrm{l}$ of sample buffer $\times 4$ prepared as reported on the Protein Standard protocol (Precision Plus Protein Standards, Bio-Rad Laboratories Inc.). Fifteen microliters of each sample was applied on a $15 \%$ SDS-PAGE gel and runs were performed until the dye front reached the bottom of the gels. Gels were stained with Colloidal Coomassie blue G250 (Májek et al. 2013) and images were recovered by Protein Expression 1680 Pro.

\section{Results and discussion}

\section{Analysis of the geo1 gene in Geosmithia species}

The complete genomic sequence encoding the class II hydrophobin GEO1 was amplified and sequenced in 26 Geosmithia species (Table 1), and belonged to 18 different haplotypes. Geosmithia sp. 5 shared the same haplotype with Geosmithia microcorthyli, Geosmithia rufescens and Geosmithia sp. 13, and Geosmithia eupagioceri had an identical haplotype as Geosmithia spp. 25 and 26.

In all the Geosmithia species analysed the gene maintained the general organization described in Geosmithia sp. 5 strain IVV7 comprising three exons and two introns in conserved positions, as determined based on the homology with the IVV7 gene and the GT/AG consensus for intron boundaries. The size of the genomic sequence varied from 440 to $502 \mathrm{bp}$ due to length differences in both introns, which ranged from 56 to $108 \mathrm{bp}$ and from 64 to $71 \mathrm{bp}$ for the first and second intron, respectively, and in the first exon $(172-208 \mathrm{bp})$. The size of the second ( $86 \mathrm{bp}$ ) and third exon (45 bp), on the other hand, was invariant. Size variability in the first exon was due to the presence of an intragenic tandem repeat (ITR) sequence (GGT/C) 11 at positions +73 to +105 in the IVV7 gene, corresponding to 11 glycine residues in the GEO1 protein. The number of repeated units was found to be highly variable in the Geosmithia species analysed, ranging from 13 in Geosmithia sp. 23 and in
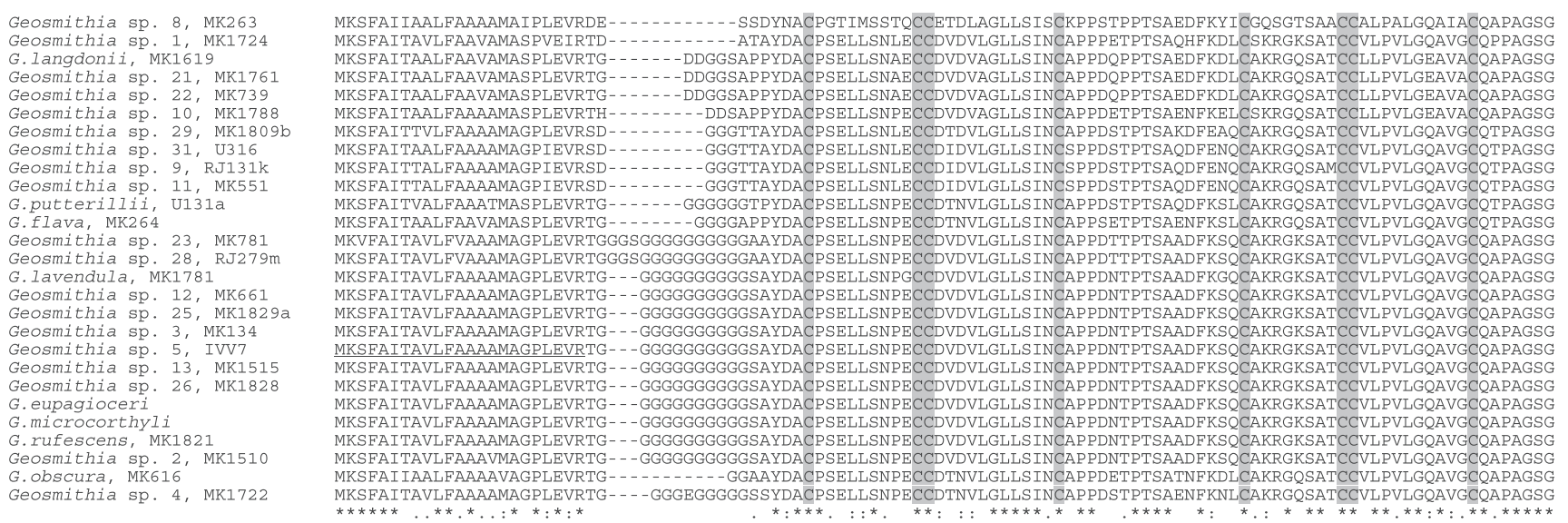

Fig 2 - MUSCLE alignment of the deduced GEO1 amino acid sequences from the different Geosmithia species. Strain number is indicated after the species name. The eight cysteine residues are highlighted in grey. The sequence of the signal peptide is underlined in the reference species Geosmithia sp. 5 strain IVV7. Symbols: (*) indicates invariant amino acid positions, (:) indicates conserved substitutions, (.) indicates semi-conserved substitutions. 
Geosmithia sp. 28 to the loss of the entire sequence in the spp. 1,8 and 10. However, as the ITR was composed of trinucleotide repeats, its length variation did not lead to frameshift mutations and the downstream hydrophobin amino acid sequence was maintained. The presence of poly-glycine traits of variable length was found in some class II hydrophobins, such as cryparin from Cryphonectria parasitica (Zhang et al. 1994) and CMO1 from Cordyceps militaris (UniProtKB accession no. G3JBA7), but up to now no function has been ascribed to such regions. Interestingly, in modular hydrophobins such as Claviceps fusiformis CFTH1 (de Vries et al. 1999) and Claviceps purpurea CPPH1 (Mey et al. 2003) hydrophobin domains are connected by gly-rich regions and similar gly-rich N-terminal repeats have been found in Trichoderma harzianum Qid3 (Lora et al. 1995) and Cladosporium fulvum HCf-6 (Nielsen et al. 2001) hydrophobins.

Genes containing ITRs of different length have been identified in the genomes of various fungi, and a significant proportion of their encoded proteins has been shown to be coating the outer cell wall and to participate in cell-to-cell or cell-tosubstrate adhesion (Verstrepen et al. 2005; Levdansky et al. 2007; Gibbons \& Rokas 2009). Intragenic tandem repeats are known regions of genomic instability mainly due to DNA polymerase slippage during replication and to unequal crossingover (Levinson \& Gutman 1987; Tautz \& Schlotterer 1994; Bichara et al. 2006). As a consequence ITR-containing proteins are evolutionarily less conserved, what led to the hypothesis that fungal ITRs may be implicated in the rapid generation of variation in cell surface proteins and molecules with active roles in the colonization of host tissue (Verstrepen et al. 2005; Levdansky et al. 2007). In Saccharomyces cerevisiae, for example, an increase in the number of repeats in the FLO1 adhesinencoding gene was correlated with an increase in cell-tosubstrate or cell-to-cell adhesion (Verstrepen et al. 2005).

When the nucleotide sequences were aligned (Supplementary Material) a high level of variability was observed, comprising both single nucleotide polymorphisms and indels. Polymorphism was therefore analysed with the program DnaSP v5 by calculating nucleotide diversity $(\pi)$, i.e. the average number of nucleotide differences per site between all pairs of sequences (Table 2). As expected, the highest nucleotide diversity was found in the non coding regions and in particular in the second intron, whose $\pi$ value was 1.6fold higher than that of the transcriptional unit.

PhyML 3.0 was then used to construct a phylogenetic tree based on the geo1 genomic sequence (Fig 1) which showed several clusters, the main one comprising 13 species with IVV7like sequences. Interestingly, the phylogeny based on the geo1 sequence did not correspond to the tree obtained with a neutral marker (ITS rDNA, Fig. 1). The ambrosia species G. microcorthyli, G. eupagioceri and G. rufescens, the specialists Geosmithia spp. 12 and 13, Geosmithia spp. 2, 3 and 5 and the related species Geosmithia lavendula, that had almost identical geo1 sequences, belonged in fact to very distant lineages in the ITS tree, and the same was true for Geosmithia spp. 9, 22 and 28. In contrast, G. microcorthyli and Geosmithia sp. 8 that have identical ITS rDNA sequences, had very different geo1 sequences. This suggested that geo1 was under strong selection and that its similarity was influenced by factors different from phylogenetic relatedness. Which factors were the main was not clear, even if the case of Geosmithia sp. 8 and G. microcorthyli suggested that the intimacy of the symbiosis with the insect vectors could be one of them, as the former is surely a less intimate symbiont than ambrosia species. The hypothesis of a strong selection pressure on the geo1 sequence was sustained by the ratios of non synonymous to synonymous nucleotide substitutions $(\mathrm{Ka} / \mathrm{Ks})$ calculated on the geo1 coding region, which were less than one for all pairwise comparisons of the 27 sequences including the reference species Geosmithia sp. 5 strain IVV7 (Table 3), suggesting that purifying (negative) selection might act on this gene.

The evolution of highly conserved gene families has often been described by the birth-and-death model, involving gene duplication followed by preservation of some gene copies and loss or pseudogenization of others. Sequence conservation is then ensured by purifying selection. This process generates groups of functionally similar paralogous proteins, offered to natural selection (Nei et al. 2000; Nei \& Rooney 2005; Jiang et al. 2006). Such a mechanism is prominent in the evolution of fungal hydrophobins, as was found in Trichoderma (Kubicek et al. 2008), Paxillus (Rajashekar et al. 2007) and Phlebiopsis (Mgbeahuruike et al. 2012). As we showed, the GEO1 sequences from unrelated Geosmithia species can be very similar, a finding that can be ascribed to strong purifying selection. An alternative explanation could be the presence of horizontal gene transfer, already detected in other Geosmithia hydrophobin proteins (Bettini et al. 2014), that will better explain the presence of very similar or even identical nucleotide sequences in different species. Such a model of evolution, involving either multiple horizontal transfer events and/or birth-and-death, was recently proposed in Fusarium for the fumonisin biosynthetic gene cluster (Proctor et al. 2013).

\section{Analysis of the deduced GEO1 proteins in Geosmithia species}

The geo1 coding sequences were translated with the Translate tool at the ExPASy Bioinformatics Resource Portal. Primary sequence length for the premature proteins varied from 100 to 112 amino acids, and the presence of a putative signal peptide could be inferred based on the comparison with the reference GEO1 sequence from Geosmithia sp. 5 strain IVV7, where a 23 amino acid signal peptide had been identified (Bettini et al. 2012).

The alignment of the deduced amino acid sequences (Fig 2) showed that all the proteins had eight cysteine residues in conserved positions, a distinctive feature of hydrophobins. Homology level was high, with 50 amino acids over 112 (44.6\%) fully conserved and 12 (10.7\%) conservative substitutions. Thus, most polymorphisms at the nucleotide level in the coding region led to synonymous substitutions in the protein.

To assess if the observed amino acid changes could determine modifications of the biochemical properties of the deduced proteins, molecular weight, theoretical pI and grand average of hydropathicity index (GRAVY) were calculated with the ProtParam tool on the amino acid sequences. As no data were available on the signal peptide cleavage site, except for Geosmithia sp. 5 strain IVV7, calculations were performed starting from the first conserved cysteine residue. Molecular weight value range was from $6740.6 \mathrm{Da}$ in Geosmithia sp. 8 to $7044.9 \mathrm{Da}$ in Geosmithia sp. 9, while the theoretical pI varied 

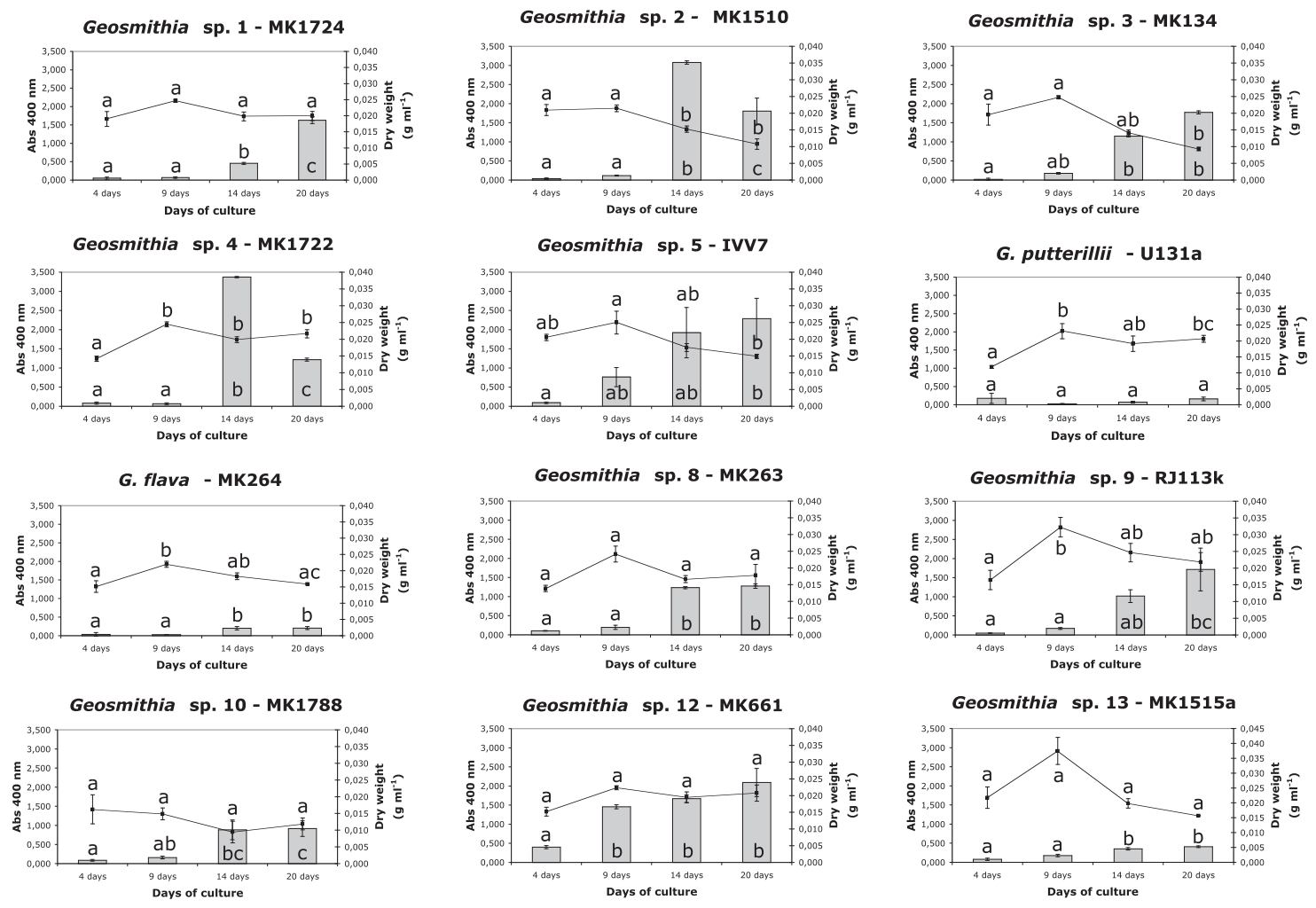

G. langdonii - MK1619
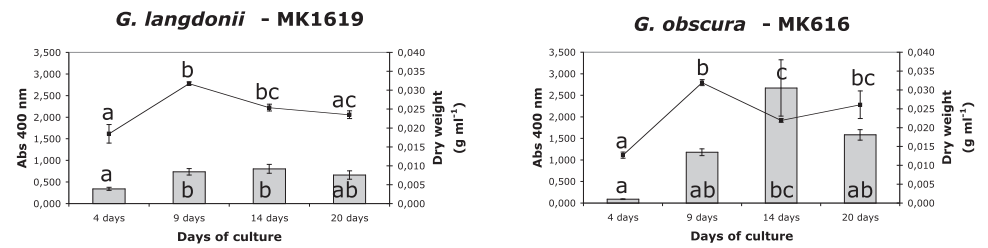

G. lavendula - MK1781
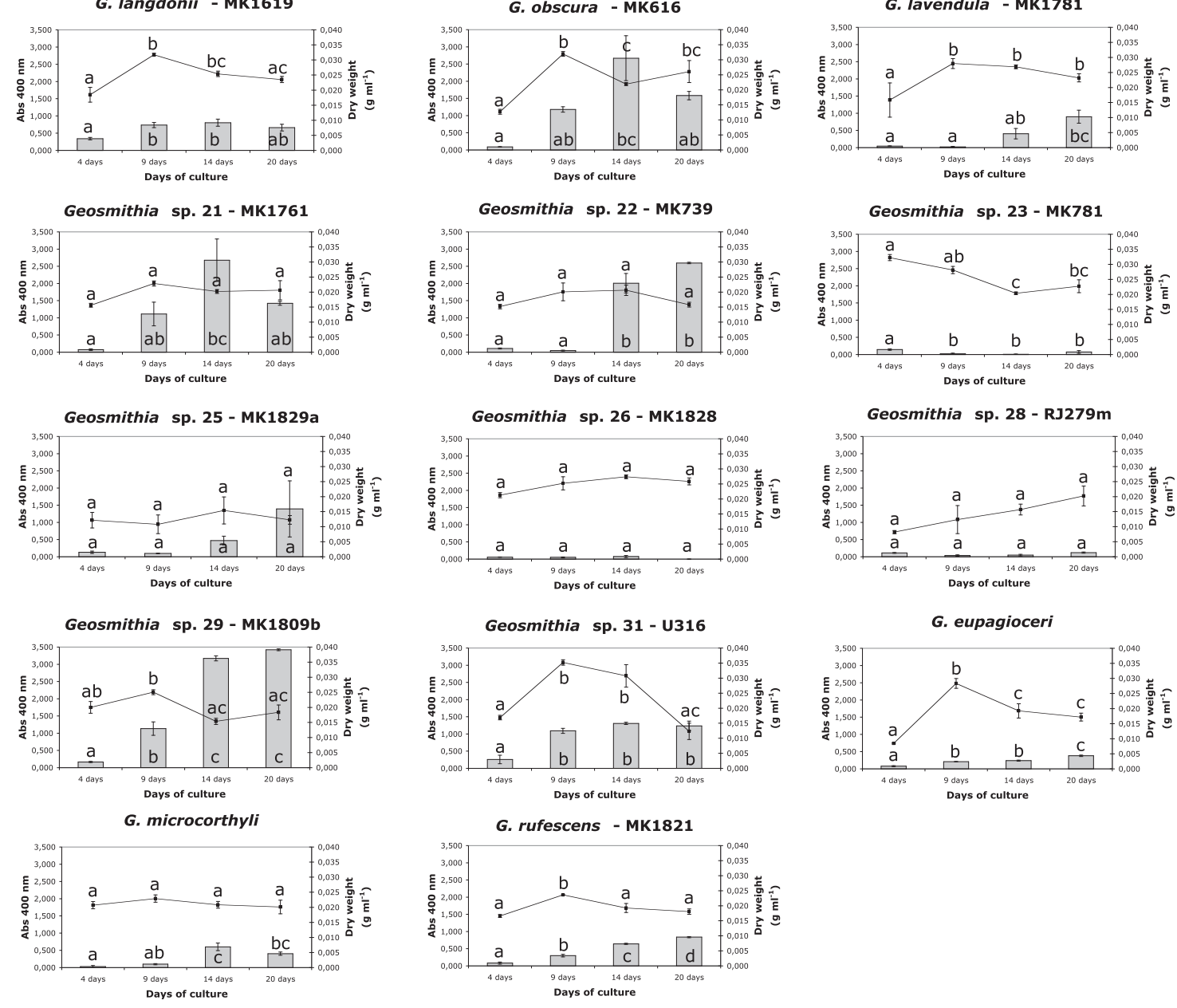

G. rufescens - MK1821

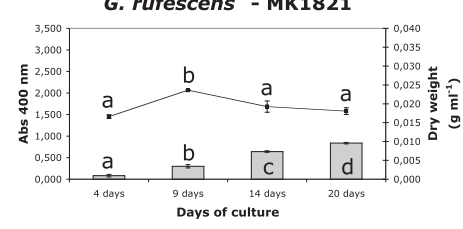



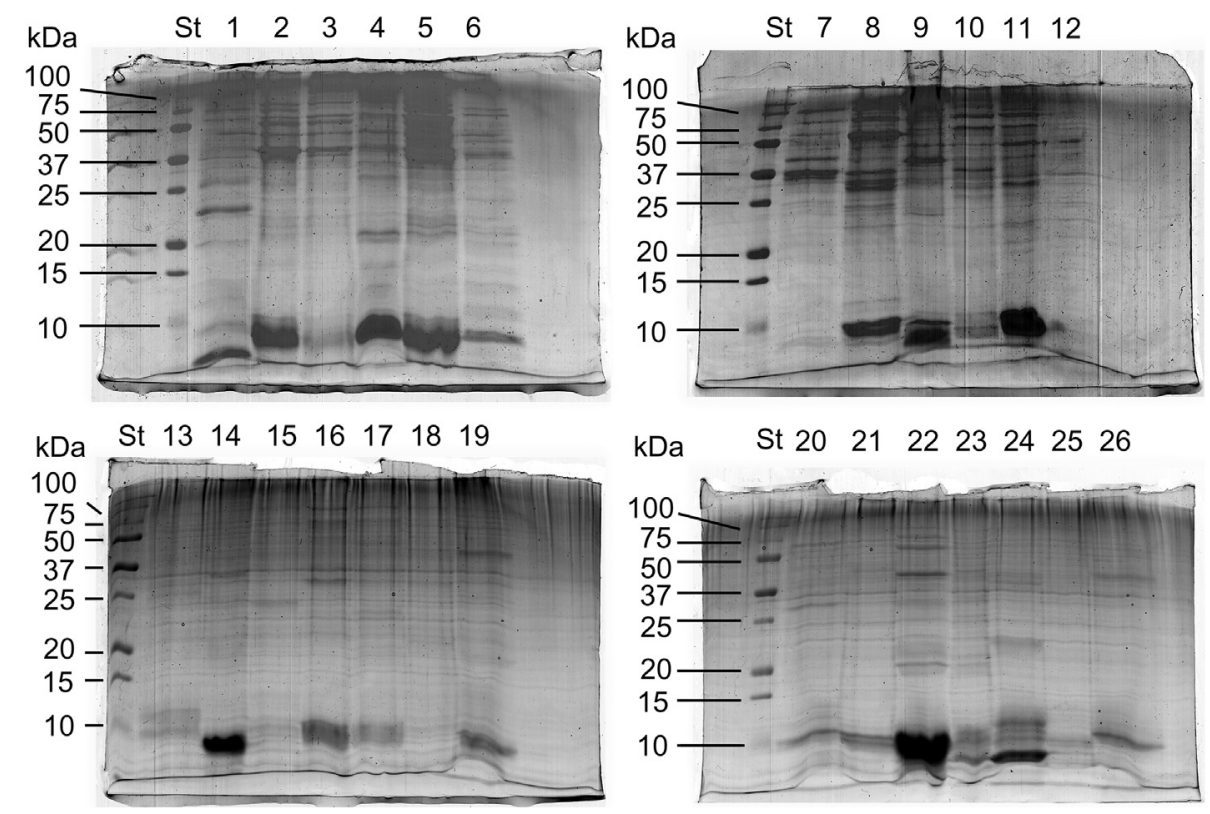

Fig 4 - Acrylamide gels of culture filtrates from the different Geosmithia species after $20 \mathrm{~d}$ of growth in shaken culture. Gels were stained with Colloidal Coomassie blue G250. St, molecular weight standard (Precision Plus Protein Standards, Bio-Rad Laboratories Inc.); 1, Geosmithia sp. 1 strain MK1724; 2, Geosmithia sp. 2 strain MK1510; 3, Geosmithia sp. 3 strain MK134; 4 , Geosmithia sp. 4 strain MK1722; 5, Geosmithia sp. 5 strain IVV7; 6, Geosmithia putterillii strain U131a; 7, Geosmithia flava strain MK264; 8, Geosmithia sp. 8 strain MK263; 9, Geosmithia sp. 9 strain RJ113k; 10, Geosmithia sp. 10 strain MK1788; 11, Geosmithia sp. 12 strain MK661; 12, Geosmithia sp. 13 strain MK1515a; 13, Geosmithia langdonii strain MK1619; 14, Geosmithia obscura strain MK616; 15, Geosmithia lavendula strain MK1781; 16, Geosmithia sp. 21 strain MK1761; 17, Geosmithia sp. 22 strain MK739; 18, Geosmithia sp. 23 strain MK781; 19, Geosmithia sp. 25 strain MK1829a; 20, Geosmithia sp. 26 strain MK1828; 21. Geosmithia sp. 28 strain RJ279m; 22, Geosmithia sp. 29 strain MK1809b; 23, Geosmithia sp. 31 strain U316; 24, Geosmithia eupagioceri; 25, Geosmithia microcorthyli; 26, Geosmithia rufescens strain MK1821.

from 3.9 (Geosmithia sp. 31) to 4.95 in Geosmithia sp. 1. The average GRAVY index was 0.142 , indicating that the deduced proteins were hydrophobic, the lowest value being 0.086 (Geosmithia spp. 11 and 31) while the highest was 0.249 (Geosmithia sp. 8). However, hydropathy plots for premature proteins obtained with ProtScale, showed that the region upstream to the first conserved cysteine was hydrophilic, so the GRAVY values for mature proteins could be less hydrophobic (data not shown). On the other hand the $\mathrm{N}$-terminal regions, corresponding to the putative signal peptides, were highly hydrophobic as expected. Structure models were also obtained with Swiss Model using the HFBII protein from Trichoderma reesei (PDB ID 1R2M) as template, and showed that all the GEO1 proteins analysed had an $\alpha$-helix, four antiparallel $\beta$-sheets and four loops (data not shown), coherently with the general structure of hydrophobins determined so far (de Vocht et al. 1998; Hakanpää et al. 2004; Kubicek et al. 2008).

In conclusion, the observed variability did not significantly change either the biochemical properties or the predicted structure of the different GEO1 proteins. Of course, we cannot exclude differences in the biological activity of these proteins as suggested by the incongruencies between the phylogenetic trees obtained with a neutral marker or with the geo1 sequence.

Finally, GEO1 release in the culture medium of the 26 Geosmithia spp. under study and of the reference species Geosmithia sp. 5 strain IVV7 was assessed with a turbidimetric assay as described in section 2.4. GEO1 production was detected in shaken cultures (Fig 3), while in the static ones no protein was present throughout the entire experimental time (data not shown). Values for species 11, strain MK551, could not be determined as after $14 \mathrm{~d}$ of growth culture filtrates turned black. The growth curves reached plateau between 4 and $9 \mathrm{~d}$, while the highest GEO1 production levels were reached between 14 and $20 \mathrm{~d}$. Results also showed that the GEO1 excretion rate was highly variable, with some species (Geosmithia spp. 2, 4, 21, 29, G. obscura) releasing a significantly higher amount of protein in the culture

Fig 3 - GEO1 production in the culture medium (grey bars) and growth curves (black lines) of the 26 Geosmithia species used in this study after 4, 9, 14 and 20 d of growth in liquid shaken culture. The reference species Geosmithia sp. 5 strain IVV7 was included as control. Each point is the average of at least three replicates \pm standard error. Tukey test was used to determine the statistical significance of the observed differences, same letters indicating that values are not significantly different at $P<0.05$ to $P<\mathbf{0 . 0 0 0 1}$. To allow immediate comparison of the data, the scales of the $y$ axes are the same for each fungal species. 
medium, as determined by Tukey test (data not shown), in comparison to others (Geosmithia putterillii, Geosmithia flava, G. eupagioceri, Geosmithia spp. 13, 23, 26, 28) that released nil or very low amount. Culture filtrates after $20 \mathrm{~d}$ of growth were subjected to PAGE and Coomassie staining (Fig 4), which showed that a major band of the expected size was present in all the species where GEO1 had been detected in the culture medium.

Also species in the genus Ophiostoma showed a different behaviour with respect to the secretion of the class II hydrophobin cerato-ulmin (CU) in the culture medium: Ophiostoma novo-ulmi and Ophiostoma himal-ulmi secreted high amounts of CU, Ophiostoma ulmi nil or low amount, while no CU was detected in Ophiostoma quercus culture medium (Brasier \& Mehrotra 1995; Scala et al. 1997). No explanation is as yet available for this observation, even if Scala et al. (1997) suggested that it could depend on differences in the regulation of $\mathrm{CU}$ synthesis and in sorting and secretion mechanisms between the Ophiostoma species.

Fungi of the genus Geosmithia are ecologically variable cosmopolite inhabitants of insect galleries, dispersed either by air or via strict entomochory and displaying either saprobic or phytopathogenic lifestyles (Kolařík et al. 2007, 2008, 2011). However, in spite of the ecological interest of these fungi, no genes have been described so far that could be related to their lifestyle. In the present paper we showed that 26 Geosmithia species possessed the class II hydrophobin GEO1 gene, and investigated the interspecific variability of the gene itself and of the deduced protein and their possible involvement in the symbiosis with the insect vectors. Hydrophobins are known to affect sporulation, attachment to insect exoskeleton and phytopathogenicity, all the traits playing an important role in Geosmithia evolution. This correlates with GEO1 features, such as the ITR region, strong selection or horizontal gene transfer, all mechanisms enabling great evolutionary plasticity.

Finally hydrophobins, besides their role in plant-fungi interactions as toxins, pathogenicity factors or pathogen fitness factors (Wösten 2001; Whiteford \& Spanu 2002; Bayry et al. 2012), have been proposed to induce the plant defence response and to possess antimicrobial activity (Ruocco et al. 2007,2009 ). We believe that the availability of new hydrophobins to be tested in this respect could also open novel opportunities for the induction of plant pathogen resistance.

\section{Conflict of interest statement}

The authors declare that they have no conflict of interest.

\section{Acknowledgements}

This work is dedicated to the memory of our dear and highly esteemed friend and colleague Giovanni Del Sorbo. Research funded by the Ministero Italiano dell'Università e della Ricerca Scientifica (MIUR), Progetti di Ricerca di Interesse Nazionale (2009RZ94KA_001) 2009 to A. Scala. M. Kolařík was supported by the grant GACR P506/11/2302.

\section{Appendix A. Supplementary data}

Supplementary data related to this article can be found at http://dx.doi.org/10.1016/j.funbio.2014.07.005.

R E F E R E N C E S

Bayry J, Aimanianda V, Guijarro JI, Sunde M, Latgé J-P, 2012. Hydrophobins - unique fungal proteins. PLOS Pathogens 8: e1002700.

Bettini PP, Frascella A, Kolařík M, Comparini C, Pepori AL, Santini A, Scala F, Scala A, 2014. Widespread horizontal transfer of the cerato-ulmin gene between Ophiostoma novo-ulmi and Geosmithia species. Fungal Biology 118: 663-674. http: //dx.doi.org/10.1016/j.funbio.2014.04.007.

Bettini PP, Frascella A, Comparini C, Carresi L, Pepori AL, Pazzagli L, Cappugi G, Scala F, Scala A, 2012. Identification and characterization of GEO1, a new class II hydrophobin from Geosmithia spp. Canadian Journal of Microbiology 58: 965-972.

Bichara M, Wagner J, Lambert IB, 2006. Mechanisms of tandem repeat instability in bacteria. Mutation Research/Fundamental and Molecular Mechanisms of Mutagenesis 598: 144-163.

Brasier CM, Mehrotra MD, 1995. Ophiostoma himal-ulmi sp. nov., a new species of Dutch elm disease fungus endemic to the Himalayas. Mycological Research 99: 205-215.

Čížková D, Šruotka P, Kolařík M, Kubátová A, Pažoutová S, 2005. Assessing the pathogenic effect of Fusarium, Geosmithia and Ophiostoma fungi from broad-leaved trees. Folia Microbiologica 50: 59-62.

de Vocht ML, Scholtmeijer K, van der Vegte EW, de Vries $\mathrm{OMH}$, Sonveaux N, Wösten HAB, Ruysschaert J-M, Hadziioannou G, Wessels JGH, Robillard GT, 1998. Structural characterization of the hydrophobin SC3, as a monomer and after self-assembly at hydrophobic/hydrophilic interfaces. Biophysical Journal 74: 2059-2068.

de Vries OMH, Moore S, Arntz C, Wessels JGH, Tudzynski P, 1999. Identification and characterization of a tri-partite hydrophobin from Claviceps fusiformis. A novel type of class II hydrophobin. European Journal of Biochemistry 262: 377-385.

Edgar RC, 2004. MUSCLE: multiple sequence alignment with high accuracy and high throughput. Nucleic Acids Research 32: 1792-1797.

Gasteiger E, Gattiker A, Hoogland C, Ivanyi I, Appel RD, Bairoch A, 2003. ExPASy: the proteomics server for in-depth protein knowledge and analysis. Nucleic Acids Research 31: 3784-3788.

Gibbons JG, Rokas A, 2009. Comparative and functional characterization of intragenic tandem repeats in 10 Aspergillus genomes. Molecular Biology and Evolution 26: 591-602.

Guindon S, Dufayard JF, Lefort V, Anisimova M, Hordijk W, Gascuel O, 2010. New algorithms and methods to estimate maximum-likelihood phylogenies: assessing the performance of PhyML 3.0. Systematic Biology 59: 307-321.

Hakanpää J, Paananen A, Askolin S, Nakari-Setälä T, Parkkinen T, Penttilä M, Linder MB, Rouvinen J, 2004. Atomic resolution structure of the HFBII hydrophobin, a self-assembling amphiphile. Journal of Biological Chemistry 279: 534-539.

Hammer $\varnothing$, Harper DAT, Ryan PD, 2001. PAST: paleontological statistics software package for education and data analysis. Paleontologia Electronica 4: 1-9.

Jiang RH, Tyler BM, Whisson SC, Hardham AR, Govers F, 2006. Ancient origin of elicitin gene clusters in Phytophthora genomes. Molecular Biology and Evolution 23: 338-351.

Kolař́k M, 2012. Evolution, diversity and ecology of the genus Geosmithia with emphasis on Geosmithia morbida. Phytopathology 102: 159. 
Kolařík M, Freeland M, Utlet C, Tisserat N, 2011. Geosmithia morbida sp. nov., a new phytopathogenic species living in symbiosis with the walnut twig beetle (Pityophthorus juglandis) on Juglans in USA. Mycologia 103: 325-332.

Kolař́k M, Jankowiak R, 2013. Vector affinity and diversity of Geosmithia fungi living on subcortical insects inhabiting Pinaceae species in central and northeastern Europe. Microbial Ecology 66: 682-700.

Kolařík M, Kirkendall LR, 2010. Evidence for a new lineage of primary ambrosia fungi in Geosmithia Pitt (Ascomycota: Hypocreales). Fungal Biology 114: 676-689.

Kolařík M, Kostovčík M, Pažoutová S, 2007. Host range and diversity of the genus Geosmithia (Ascomycota: Hypocreales) living in association with bark beetles in the Mediterranean area. Mycological Research 111: 1298-1310.

Kolařík M, Kubátová A, Čepička I, Pažoutová S, Šrůtka P, 2005. A complex of three new white-spored, sympatric and host range limited Geosmithia species. Mycological Research 109: 1323-1336.

Kolařík M, Kubátová A, Hulcr J, Pažoutová S, 2008. Geosmithia fungi are highly diverse and consistent bark beetle associates: evidence from their community structure in temperate Europe. Microbial Ecology 55: 65-80.

Kolař́ík M, Kubátová A, Pažoutová S, Šrůtka P, 2004. Morphological and molecular characterisation of Geosmithia putterillii, G. pallida comb. nov. and G. flava sp. nov., associated with subcorticolus insects. Mycological Research 108: 1053-1069.

Kubicek C, Baker S, Gamauf C, Kenerley CM, Druzhinina IS, 2008. Purifying selection and birth-and-death evolution in the class II hydrophobin gene families of the ascomycete Trichoderma/Hypocrea. BMC Evolutionary Biology 8: 4.

Levdansky E, Romano J, Shadkchan Y, Sharon H, Verstrepen KJ, Fink GR, Osherov N, 2007. Coding tandem repeats generate diversity in Aspergillus fumigatus genes. Eukaryotic Cell 6: 1380-1391.

Levinson G, Gutman GA, 1987. Slipped-strand mispairing: a major mechanism for DNA sequence evolution. Molecular Biology and Evolution 4: 203-221.

Librado P, Rozas J, 2009. DnaSP v5: a software for comprehensive analysis of DNA polymorphism data. Bioinformatics 25: 1451-1452.

Linder MB, Szilvay GR, Nakari-Setälä T, Penttilä ME, 2005. Hydrophobins: the protein-amphiphiles of filamentous fungi. FEMS Microbiology Reviews 29: 877-896.

Lora JM, Pintor-Toro JA, Benitez T, Romero LC, 1995. Qid3 protein links bimodular proteins with fungal hydrophobins. Molecular Microbiology 18: 380-382.

Májek P, Riedelová-Reicheltová Z, Suttnar J, Dyr JE, 2013. Staining of proteins for 2D SDS-PAGE using Coomassie Blue-speed versus sensitivity? Electrophoresis 34: 1972-1975.

McPherson BA, Erbilgin N, Bonello P, Wood DL, 2013. Fungal species assemblages associated with Phytophthora ramoruminfected coast live oaks following bark and ambrosia beetle colonization in northern California. Forest Ecology and Management 291: 30-42.

Mey G, Correia T, Oeser B, Kershaw MJ, Garre V, Arntz C, Talbot NJ, Tudzynski P, 2003. Structural and functional analysis of an oligomeric hydrophobin gene from Claviceps purpurea. Molecular Plant Pathology 4: 31-41.

Mgbeahuruike AC, Karlsson M, Asiegbu FO, 2012. Differential expression of two hydrophobin genes (Pgh1 and Pgh2) from the biological control agent Phlebiopsis gigantea. Fungal Biology 116: 620-629.

Nei M, Rogozin IB, Piontkivska H, 2000. Purifying selection and birth-and-death evolution in the ubiquitin gene family. Proceedings of the National Academy of Sciences USA 97: $10866-10871$.

Nei M, Rooney AP, 2005. Concerted and birth-and-death evolution of multigene families. Annual Reviews of Genetics 39: 121-152.
Nielsen PS, Clark AJ, Oliver RP, Huber M, Spanu PD, 2001. HCf-6, a novel class II hydrophobin from Cladosporium fulvum. Microbiological Research 156: 59-63.

Proctor RH, Van Hove F, Susca A, Stea G, Busman M, van der Lee T, Waalwijk C, Moretti A, Ward TJ, 2013. Birth, death and horizontal transfer of the fumonisin biosynthetic gene cluster during the evolutionary diversification of Fusarium. Molecular Microbiology 90: 290-306.

Rajashekar B, Samson P, Johansson T, Anders T, 2007. Evolution of nucleotide sequences and expression patterns of hydrophobin genes in the ectomycorrhizal fungus Paxillus involutus. New Phytologist 174: 399-411.

Ruocco M, Lanzuise S, Turrà D, Vinale F, Marra R, Woo SL, Lorito M, 2007. Hytra1 from the beneficial fungus Trichoderma harzianum T22 is an elicitor of defence responses in plants. Journal of Plant Pathology 89 (3, Supplement): S21.

Ruocco M, Lanzuise S, Woo SL, Reverberi M, Marra R, Vinale F,V, Aloj V, Scala F, Lorito M, 2009. A new hydrophobin that affects the interaction between Trichoderma harzianum and the plant 11th SIFV Congress. http://www.fisv.org/index.php/it/annualmeeting/2009/posters/poster-session-ii P18.6.

Scala A, Tegli S, Comparini C, Mittempergher L, Scala F, Del Sorbo G, 1994. Influence of fungal inoculum on cerato-ulmin production; purification of cerato-ulmin and detection in elm sucker cuttings. Petria 4: 57-67.

Scala F, Bertelli E, Coppola L, Del Sorbo G, Tegli S, Scala A, 1997. Comparative determination of cerato-ulmin on cell surface and in mycelial extracts of pathogenic and non-pathogenic Ophiostoma species. Mycological Research 101: 829-834.

Stodůlková E, Kolařík M, Křesinová Z, Kuzma M, Šulc M, Man P, Novák P, Maršik P, Landa P, Olšovská J, Chudíčková M, Pažoutová S, Černý J, Bella J, Flieger M, 2009. Hydroxylated anthraquinones produced by Geosmithia species. Folia Microbiologica 54: 179-187.

Sunde M, Kwan AHY, Templeton MD, Beever RE, Mackay JP, 2008. Structural analysis of hydrophobins. Micron 39: 773-784.

Takai S, Richards WC, 1978. Cerato-ulmin, a wilting toxin of Ceratocystis ulmi: isolation and some properties of cerato-ulmin from the culture of C. ulmi. Phytopathologische Zeitschrift 91: 129-146.

Tamura K, Peterson D, Peterson N, Stecher G, Nei M, Kumar S, 2011. MEGA5: Molecular Evolutionary Genetics Analysis using maximum likelihood, evolutionary distance, and maximum parsimony methods. Molecular Biology and Evolution 28: 2731-2739.

Tautz D, Schlotterer C, 1994. Simple sequences. Current Opinion in Genetics \& Development 4: 832-837.

Temple B, Horgen PA, 2000. Biological roles for cerato-ulmin, a hydrophobin secreted by the elm pathogens, Ophiostoma ulmi and O. novo-ulmi. Mycologia 92: 1-9.

Verstrepen KJ, Jansen A, Lewitter F, Fink GR, 2005. Intragenic tandem repeats generate functional variability. Nature Genetics 37: 986-990.

Whiteford JR, Spanu PD, 2002. Hydrophobins and the interactions between fungi and plants. Molecular Plant Pathology 3: 391-400.

Wösten HAB, 2001. Hydrophobins: multipurpose proteins. Annual Reviews of Microbiology 55: 625-646.

Wösten HAB, Schuren FHJ, Wessels JGH, 1994. Interfacial selfassembly of a hydrophobin into an amphipathic protein membrane mediates fungal attachment to hydrophobic surfaces. The EMBO Journal 13: 5848-5854.

Zhang L, Villion D, Sun Y, Kazmierczak P, Van Alfen NK, 1994. Virus-associated down-regulation of the gene encoding cryparin, an abundant cell-surface protein from the chestnut blight fungus, Cryphonectria parasitica. Gene 139: 59-64.

Zhang S, Xia YX, Kim B, Keyhani NO, 2011. Two hydrophobins are involved in fungal spore coat rodlet layer assembly and each play distinct roles in surface interactions, development and pathogenesis in the entomopathogenic fungus, Beauveria bassiana. Molecular Microbiology 80: 811-826. 